\title{
HUBUNGAN DUKUNGAN SUAMI DENGAN KUNJUNGAN ANTENATAL CARE (ANC) PADA IBU HAMIL DI KABUPATEN TABANAN
}

\author{
Hesteria Friska Armynia Subratha ${ }^{1}$, Ni Wayan Manik Kartiningsih ${ }^{1}$ \\ ${ }^{1}$ Prodi D III Kebidanan, Stikes Advaita Medika Tabanan \\ Email: hesteria.friska@yahoo.com
}

\begin{abstract}
Abstrak
Latar Belakang dan tujuan: Kehamilan adalah suatu krisis maturitas yang dapat menimbulkan stres. Tingginya cakupan K1 dan K4 tentunya sangat didukung oleh peran keluarga, dukungan keluarga salah satunya adalah dukungan suami. Tujuan penelitian ini adalah untuk mengetahui apakah ada hubungan dukungan suami dengan kunjungan antenatal care (ANC) pada ibu hamil di Bidan Praktek Mandiri Ny.MD Desa Cau, Kecamatan Marga, Kabupaten Tabanan.

Metode: Desain penelitian ini adalah servei analitik dengan pendekatan cross-sectional. Penelitian dilakukan pada bulan Juli 2014. Teknik sampel yang digunakan adalah total sampling dengan jumlah sebanyak 50 orang. Teknik analisa data menggunakan chi square test.

Hasil: Hasil penelitian menunjukkan bahwa Sebagian besar responden di BPM"MD" Desa Cau Kecamatan Marga Kabupaten Tabanan kurang mendapatkan dukungan suami. Sebagian besar responden di BPM"MD" Desa Cau Kecamatan Marga Tabanan sesuai standar kunjungan ANC. Ada hubungan yang signifikan dukungan suami dengan kunjungan ANC pada ibu hamil di BPM" MD” Desa Cau Kecamatan Marga Tabanan.

Simpulan: Responden di BPM"MD" Desa Cau Kecamatan Marga Kabupaten Tabanan kurang mendapatkan dukungan suami sebanyak 26 responden (52\%).
\end{abstract}

Kata kunci : Dukungan Suami, ANC, Ibu Hamil

\section{PENDAHULAN}

Kehamilan adalah suatu krisis maturitas yang dapat menimbulkan stres tetapi berharga karena wanita tersebut menyiapkan diri untuk memberi perawatan dan mengemban tanggung jawab yang lebih besar. Seiring persiapanya untuk menghadapi peran baru wanita mengubah konsep dirinya supaya dia siap menjadi orang tua (Rukiyah, 2009). Saat ini angka kematian ibu di Indonesia masih tetap tinggi di kawasan Association of South East Asia Nations (ASEAN). Hasil Survei Demografi dan Kesehatan Indonesia (SDKI) 2012, menunjukkan Angka Kematian Bayi (AKB) 34/1000 Kelahiran Hidup (KH), Angka Kematian
Balita (AKBA) 44/1000 KH dan Angka Kematian Ibu (AKI) 228/100.000 KH. Target pencapaian sasaran di tahun 2015 yaitu AKB 23/1000 KH dan AKBA 32/1000 KH. Salah satu upaya yang dilakukan Departemen Kesehatan dalam rangka mempercepat penurunan angka kematian ibu dan bayi adalah pendekatan pelayanan kesehatan maternal dan neonatal yang berkualitas, yaitu melakukan kunjungan pemeriksaan kehamilan atau Antenatal Care (ANC). Tujuan dari ANC adalah untuk menjaga agar ibu hamil dapat melalui masa kehamilan, persalinan dan nifas dengan baik dan selamat, serta menghasilkan bayi yang sehat ( Depkes RI, 2008). 
Kunjungan antenatal sebaiknya dilakukan secara berkala dan teratur, bila kehamilan berjalan normal jumlah kunjungan cukup empat kali yaitu satu kali pada trimester I, satu kali pada trimester ke II, dan dua kali pada trimester III. Tindakan ini dapat memberikan peluang yang lebih besar bagi petugas kesehatan untuk mengenali secara dini berbagai penyulit atau gangguan kesehatan yang terjadi pada ibu hamil (Asrinah, 2010).

Cakupan pelayanan ANC dapat dipantau melalui pelayanan kunjungan baru ibu hamil (KI) untuk melihat akses dan pelayanan kesehatan ibu hamil sesuai standar paling sedikit empat kali (K4) dengan distribusi sekali pada trimester pertama, sekali pada trimester kedua dan dua kali pada trimester ketiga. Cakupan jumlah kunjungan Ibu hamil di Indonesia yaitu 85,56\%, sedangkan jumlah cakupan Ibu hamil di Provinsi Bali yaitu 90,07\%, cakupan jumlah kunjungan Ibu hamil di Kabupaten Tabanan yaitu 96,3\% dan jumlah cakupan kunjangan ibu hamil di BPM Ny.MD yaitu 45\% (Dinkes, 2013).

Tingginya cakupan K1 dan K4 tentunya sangat di dukung oleh peran keluarga, dukungan keluarga salah satunya adalah dukungan suami. Dukungan suami dapat diterjemahkan sebagai sikap-sikap penuh pengertian yang ditunjukkan dalam bentuk kerjasama yang positif, ikut membantu menyelesaikan pekerjaan rumah tangga, membantu mengurus anak-anak serta memberikan dukungan moral dan emosional terhadap istrinya dukungan suami selama kehamilan antara lain mengajak istri jalan-jalan ringan, menemani istri memeriksakan kehamilannya, tidak membuat masalah dalam berkomunikasi (Lusa, 2011).

Perubahan dan adaptasi selama kehamilan, tidak hanya dirasakan oleh ibu tetapi seluruh anggota keluarga. Oleh karena itu, selama kehamilan seluruh anggota keluarga harus terlibat terutama suami. Dukungan dan kasih sayang dari suami serta anggota keluarga dapat memberikan perasaan nyaman dan aman ketika ibu merasa takut dan khawatir dengan kehamilanya. Salah satu dukungan suami yang lain dalam kehamilan ibu yaitu kunjungan atau kegiatan dalam pemeriksaan rutin kehamilan (Lusa, 2011). Ibu hamil sangat memerlukan dukungan dan perhatian, adanya dukungan ini menyebabkan ibu merasa nyaman dan aman dalam melewati kehamilanya. Psikologi ibu hamil sangatlah unik dan sensitive oleh karena itu dukungan yang diberikan harus serius dan maksimal. Apabila ibu melewati kehamilanya dengan perasaan tidak aman dan nyaman yang disebabkan oleh faktor lingkungan akan menyebabkan gangguan yang berarti bagi ibu dan janin (Yulianti, 2009).

Pada penelitian di Indonesia, dukungan suami yang diharapkan istri yang sedang hamil antara lain adalah suami mendambakan bayi dalam kandungan istri, suami senang mendapat keturunan, suami menunjukan kebahagiaan pada kehamilan istri saat ini, suami memperhatikan kesehatan istri, suami menghibur atau menenangkan ketika istri menghadapi masalah, suami menasehati istri agar tidak terlalu lelah bekerja, suami membantu tugas istri, suami berdoa untuk kesehatan istri dan keselamatan ibu calon bayi, dan suami menunggu ketika istri melahirkan baik secara normal maupun operasi (Lusa, 2011).

Kunjungan ANC yang teratur dan pengawasan yang rutin dari bidan maupun dokter selama masa kehamilan diharapkan komplikasi yang mungkin terjadi selama hamil, termasuk riwayat penyakit secara umum dapat dikenali secara lebih dini. Hal ini dapat mengurangi resiko kematian ibu hamil. Faktor yang mempengaruhi pencapaian kunjungan KI dan K4 ibu hamil diantaranya adalah faktor internal (paritas dan usia) dan eksternal (pengetahuan, sikap, ekonomi, sosial budaya, geografis, informasi dan dukungan). Dampak dari ibu hamil yang tidak mengikuti ANC adalah meningkatnya angka mortalitas dan 
morbilitas ibu, tidak terdeteksinya kelainan-kelainan kehamilan dan kelainan fisik yang terjadi pada saat persalinan tidak dapat dideteksi secara dini (Depkes RI, 2008).

Berdasarkan data Dinas Kesehatan Kabupaten Tabanan data ibu hamil tahun 2013 jumlah kunjungan ibu hamil (KI) mencakup 5.245 orang $(98,04 \%)$ dan (K4) mencakup 5.161 orang $(96,47 \%)$. Dari studi pendahuluan yang kami lakukan di BPM Ny. MD Desa Cau, Kecamatan Marga pada tanggal 28 Mei 2014 mengenai dukungan suami dengan kunjungan antenatal care (ANC) pada ibu hamil, 15 orang yang memeriksakan kehamilanya di dapatkan hasil hanya enam (40\%) Ibu hamil yang memeriksakan kehamilan sesuai dengan standar, sedangkan sembilan (60\%) ibu hamil yang belum memeriksakan kehamilanya sesuai dengan standar. Kemudian dilakukan wawancara terhadap sembilan ibu hamil tersebut mengapa ibu tidak datang ke pelayanan kesehatan untuk memeriksakan kehamilannya dengan alasan ibu tidak ada yang menemani, mengantar ibu periksa ke tempat pelayanan kesehatan dan memberikan perhatian terhadap kehamilannya.

Berdasarkan uraian tersebut diatas peneliti tertarik untuk melakukan penelitian tentang hubungan dukungan suami dengan kunjungan antenatal care (ANC) pada ibu hamil di Bidan Praktek Mandiri Ny. MD Desa Cau, Kecamatan Marga, Kabupaten Tabanan. Dimana tujuan dari penelitian ini adalah untuk mengetahui hubungan dukungan suami dengan kunjungan antenatal care (ANC) pada ibu hamil di Bidan Praktek Mandiri, Ny."MD", Desa Cau, Kecamatan Marga, Kabupaten Tabanan.

\section{METODE PENELITIAN}

Penelitian ini dilaksanakan di Bidan Praktek Mandiri Ny.MD, Desa Cau, Kecamatan Marga, Kabupaten Tabanan pada bulan Juli tahun 2014. Desain penelitian yang digunakan adalah survei analitik dengan pendekatan cross sectional. Data yang digunakan adalah data primer dan data sekunder. Sampel penelitian adalah ibu hamil yang melakukan kunjungan ANC TW III yang berjumlah 50 orang dengan tehnik pengambilan sampel yaitu total sampling. Analisis data menggunakan statistik non parametrik yaitu uji chi square.

\section{HASIL DAN PEMBAHASAN}

Dari 50 responden dukungan suami sebagian kecil sebanyak 24 responden (48\%) dengan dukungan suami kategori cukup dan sebagian besar sebanyak 26 responden $(52 \%)$ dengan dukungan suami kurang. Dari 50 responden dengan kunjungan ANC sesuai standar sebagian kecil sebanyak 22 responden (44\%) dan sebagian besar sebanyak 28 responden (56\%) tidak sesuai standar.

Hubungan dukungan suami dengan kunjungan antenatal care 24 responden dengan dukungan suami kategori cukup terdapat 22 responden $(91,75)$ dengan kunjungan ANC sesuai standar. Dari 26 responden dengan dukungan suami kurang terdapat 20 responden $(76,9 \%)$ kunjungan ANC tidak sesuai standar.

Berdasarkan uji statistik menggunakan chi square test didapatkan bahwa diperoleh chi square test $\mathrm{p}=$ 0,000 berarti pada alpha 5\%, H1 diterima atau Ho ditolak yang berarti ada hubungan yang signifikan dukungan suami dengan kunjungan antenatal care pada ibu hamil di BPM" MD" Desa Cau Kecamatan Marga Tabanan Tahun 2014.

Berdasarkan hasil penelitian menunjukkan bahwa sebagian besar dukungan suami kurang sebanyak 26 responden (52\%) Hal ini berarti sebagian besar suami responden di BPM"MD” Desa Cau Kecamatan Marga Kabupaten Tabanan kurang memberi dukungan dalam melakukan kunjungan ANC.

Menurut Lia (2009), dukungan suami adalah memberikan dorongan kepada istri ke suatu upaya, usaha, dan rencana. Salah satu contoh penerapan dukungan suami yaitu suami dapat mengajak istri berjalan-jalan, menemani 
istri memeriksakan kehamilanya, tidak membuat masalah dalam berkomunikasi.

Hal ini sesuai dengan BKKBN (2001), bahwa perlunya peningkatan partisipasi suami dalam asuhan kehamilan karena suami merupakan pasangan atau patner dalam proses reproduksi, sehingga beralasan apabila suami istri berbagi tanggung jawab dan peranan secara seimbang untuk mencapai kesehatan reproduksi dan berbagi beban untuk mencegah penyakit serta kompliksi kesehatan reproduksi dan kehamilan dan suami bertanggung jawab secara sosial, moral, dan ekonomi dalam membangun keluarga, suami secara nyata terlibat dalam fertilitas dan mereka mempunyai peran yang penting dalam mengambil keputusan.

Berdasarkan hasil penelitian sebagian besar responden tidak sesuai dengan standar sebanyak 28 orang (56\%). Hal ini berarti sebagian besar responden di BPM"MD" Desa Cau Kecamatan Marga Tabanan tidak sesuai standar melakukan kunjungan ANC.

Menurut Notoatmodjo (2003) Faktor-faktor yang mempengaruhi ibu hamil melakukan kunjungan kehamilan diantaranya pengetahuan, social budaya, social ekonomi, fasilitas kesehatan, informasi/media massa. Seperti yang diungkapkan oleh Musfdlilah (2009) bahwa tujuan dari asuhan Antenatal Care adalah untuk memantau kemajuan kehamilan dan memastikan kesehatan ibu serta tumbuh kembang bayi, juga untuk meningkatkan dan mempertahankan kesehatan fisik, mental dan sosial ibu. Disamping tujuan di atas, Antenatal Care juga bertujuan untuk mengenali secara dini adanya ketidaknormalan atau komplikasi yang mungkin terjadi selama hamil termasuk riwayat penyakit secara umum, kebidanan dan pembedahan, mempersiapkan persalinan yang cukup bulan, melahirkan dengan selamat baik ibu maupun bayinya dengan trauma seminimal mngkin, mempersiapkan bu agar masa nifas berjalan normal dan pemberian ASI ekslusif, mempersiapkan peran ibu dan keluarga dalam menerima kesehatan bayi agar dapat tumbuh dan berkembang secara optimal.

Hasil penelitian menunjukkan bahwa dari 24 responden dengan dukungan suami kategori cukup hampir seluruhnya dengan kunjungan ANC sesuai standar. Dari 26 responden dengan dukungan suami kurang hampir seluruhnya kunjungan ANC tidak sesuai standar. Data hasil tabel silang menunjukkan suami yang kurang mendukung pasangannya akan menghasilkan kunjungan ANC tidak sesuai dengan standar. Berdasarkan uji statistik menggunakan chi square test didapatkan bahwa diperoleh chi square test $\mathrm{p}=0,000$ berarti pada alpha $5 \%, \mathrm{H} 1$ diterima atau Ho ditolak yang berarti ada hubungan yang signifikan dukungan suami dengan kunjungan antenatal care pada ibu hamil di BPM" MD" Desa Cau Kecamatan Marga Tabanan.

Hasil penelitian ini sesuai dengan penelitian yang dilakukan oleh Surya (2009) yang berjudul hubungan pengetahuan keluarga dengan rajinnya ibu memeriksakan kehamilannya di BPS Andarini. Dalam penelitiannya ditemukan ada hubungan yang signifikan antara pengetahuan keluarga dengan rajinnya ibu memeriksakan kehamilannya.

\section{SIMPULAN}

Responden di BPM"MD" Desa Cau Kecamatan Marga Kabupaten Tabanan kurang mendapatkan dukungan suami sebanyak 26 responden (52\%). Responden di BPM"MD" Desa Cau Kecamatan Marga Tabanan tidak sesuai standar kunjungan ANC sebanyak 28 responden (56\%). Ada hubungan yang signifikan dukungan suami dengan kunjungan ANC pada ibu hamil di BPM" MD" Desa Cau Kecamatan Marga Tabanan. 


\section{REFRENSI}

Asrinah. 2010. Medical book, Konsep

Notoatmodjo. 2010. Metodelogi

Dasar Asuhan Kehamilan .

Penelitian Kesehatan.Jakarta : PT Cipta

Yogyakarta : Nuha Medika.

Yulianti. 2009. Konsep dasar asuhan

Depkes RI. 2009. Standar Pelayanan

kebidanan. Jakarta :PT. Rineka Cipta.

Kebidanan . Jakarta : Depkes RI

Lusa. 2011. Buku Acuan Pelayanan

Kesehatan Maternal dan

Neonatal. Yogyakarta :

Yayasan Bina Pustaka. 